\title{
Human unconventional T cells in Plasmodium falciparum infection
}

\author{
Mathias Schmaler ${ }^{1} \cdot$ Nina Orlova-Fink ${ }^{1} \cdot$ Tobias Rutishauser $^{1} \cdot$ Salim Abdulla $^{2} \cdot$ Claudia Daubenberger $^{1}$ (D)
}

Received: 22 January 2020 / Accepted: 7 February 2020 / Published online: 19 February 2020

(C) Springer-Verlag GmbH Germany, part of Springer Nature 2020

\begin{abstract}
Malaria is an old scourge of humankind and has a large negative impact on the economic development of affected communities. Recent success in malaria control and reduction of mortality seems to have stalled emphasizing that our current intervention tools need to be complemented by malaria vaccines. Different populations of unconventional T cells such as mucosal-associated invariant T (MAIT) cells, invariant natural killer T (iNKT) cells and $\gamma \delta \mathrm{T}$ cells are gaining attention in the field of malaria immunology. Significant advances in our basic understanding of unconventional $\mathrm{T}$ cell biology in rodent malaria models have been made, however, their roles in humans during malaria are less clear. Unconventional $\mathrm{T}$ cells are abundant in skin, gut and liver tissues, and long-lasting expansions and functional alterations were observed upon malaria infection in malaria naïve and malaria pre-exposed volunteers. Here, we review the current understanding of involvement of unconventional $\mathrm{T}$ cells in antiPlasmodium falciparum immunity and highlight potential future research avenues.
\end{abstract}

Keywords Unconventional T cells $\cdot \gamma \delta$ T cells $\cdot$ MAIT cells $\cdot$ Vaccination $\cdot$ CHMI $\cdot$ Malaria $\cdot$ Plasmodium falciparum

\section{Malaria biology, disease burden and pathogenesis}

Malaria remains one of the most devastating infectious diseases with 228 million malaria cases globally (95\% confidence interval 206-258 million) resulting in 405,000 deaths in 2018 [172]. P. falciparum is the most prevalent malaria parasite in the WHO African Region, responsible for $99.7 \%$ of the malaria cases in 2018 [172]. Scale-up and improvements of diagnostics and access to treatment combined with vector control measures based on insecticide treated bed-nets, indoor residual spraying and larviciding have resulted in a significant reduction of malaria prevalence and deaths between 2000 and 2015 [172]. The incidence rate of malaria declined globally between 2010 and 2018; however, this progress seems to have slowed down with 251 million cases reported in 2010 and 231

This article is a contribution to the special issue on: Immunopathology of unresolved tropical diseases - Guest Editor: Marcel Tanner

Claudia Daubenberger

Claudia.Daubenberger@swisstph.ch

1 Department of Medical Parasitology and Infection Biology, Swiss Tropical and Public Health Institute, University of Basel, Basel, Switzerland

2 Ifakara Health Institute, Bagamoyo Clinical Trial Unit, Bagamoyo, Tanzania million cases in 2017 [172]. Sub-Saharan Africa is especially strongly affected by malaria - about $90 \%$ of both cases and deaths occur in this region. The most vulnerable population are children under the age of 5 years, accounting for $70 \%$ of all malaria deaths [172].

Malaria is caused by parasites of the Plasmodium genus and is transmitted to humans through bites of infected Anopheles mosquitoes [4]. The majority of malaria cases and deaths in humans are caused by $P$. falciparum, a species that is particularly prevalent in sub-Saharan Africa. During a blood meal, infected mosquitoes inject a small number of sporozoites into the skin of the human host $[16,111]$. Most sporozoites will leave the skin through blood or lymph, but recent evidence from mouse models suggests that a fraction of the sporozoites can remain in the skin for several days [62]. Sporozoites can move by gliding motility, and a fraction of the injected sporozoites will invade a blood vessel, enter the blood stream and reach the liver. Interaction between sporozoites and human hepatocytes involves circumsporozoite protein, the main surface protein of sporozoites [22]. The parasites use cell traversal to escape from the liver sinusoids into the liver parenchyma, where they can traverse several hepatocytes before setting up residence inside a parasitophorous vacuole (PV) inside a hepatocyte [109]. Within the PV, the sporozoite develops into a spherical liver stage that grows extensively and ultimately gives rise to thousands of merozoites that will then enter the blood stream. For this purpose, the parasite 
induces cell death of the hepatocyte and manipulates the hepatocyte membrane, leading to formation of parasite-filled vesicles (merosomes) containing hundreds of merozoites [150]. The duration of liver-stage development is variable between few days to several weeks in different Plasmodium species, but for $P$. falciparum, it takes about 6 days to complete [110]. The erythrocytic stage of development is characterized by repeated cycles of erythrocyte invasion, parasite replication, egress and invasion of other erythrocytes. Invasion of erythrocytes by merozoites is facilitated through specific interaction between parasite proteins and receptors on the erythrocyte surface [120]. Inside an erythrocyte, the parasite sets up residence inside a PV and develops into the ringstage, while it starts to actively remodel the host cell. It feeds on haemoglobin as well as nutrients from blood plasma and develops into a trophozoite [11]. The trophozoite stage is characterized by extensive parasite growth, sustained by ingestion of large amounts of haemoglobin, leading to accumulation of toxic haem groups, which the parasite converts into the crystalline haemozoin form and stores in its food vacuole [151]. Then, the parasite undergoes a few rounds of nuclear divisions, leading to generation of 16-32 merozoites [11]. Finally, the merozoites escape through lysis of the erythrocyte and PV membranes in a protease-dependent process [138]. The free merozoites then go on to infect other erythrocytes, completing the cyclic erythrocyte development. Successful transmission of the parasite from the human host to a mosquito involves formation of a sexual parasite stage [89]. This involves the formation of male and female gametocytes, a process that only a small fraction of blood-stage parasites undergoes. During gametogenesis, the parasite develops through five morphological stages, of which only the last one is detectable in peripheral blood. The other stages occur within erythroid precursor cells in the bone marrow, enabling early gametocytes to avoid splenic clearance $[3,85]$. When gametocytes are taken up by a mosquito during a blood meal, they sense a change in temperature, $\mathrm{pH}$ and chemical environment, inducing their development into gametes within the mosquito midgut [18]. There, male and female gametes fuse to form a short diploid stage, the zygote, which then develops into an ookinete. In the ookinete stage, meiotic recombination occurs, and the parasite traverses the epithelial cell layer in the mosquito midgut and transforms into an oocyst [12]. Ultimately, the oocyst ruptures, releasing sporozoites into the haemocoel of the mosquito from where they migrate to the salivary glands and are ready to be injected into the human host [30].

Clinical malaria is characterized by cyclic episodes of fever that are caused by synchronized rupture of infected erythrocytes, releasing large amounts of parasites and parasitederived molecules that induce a strong pro-inflammatory response. Most symptoms are relatively unspecific and include chills, headache, nausea, diarrhoea and anaemia [121]. First symptoms of $P$. falciparum malaria appear 7-10 days after infection, indicating that pre-erythrocytic stages are clinically silent, while most clinical symptoms and complications occur only upon blood-stage parasitaemia [121]. A certain degree of anaemia is induced by rupture and destruction of infected erythrocytes by blood-stage parasites. However, it has become clear that the majority of cleared erythrocytes are uninfected [83, 171]. Plasmodium parasites extensively remodel the erythrocyte and its plasma membrane by expressing a range of parasite-encoded proteins on the erythrocyte surface [178]. This leads to increased rigidity of the membrane, to binding of infected erythrocytes to endothelial cells as well as to formation of aggregates of infected and uninfected erythrocytes (rosetting) and helps the parasite to avoid splenic clearance [54]. Adherence of erythrocytes to the microvasculature leads to obstruction of blood flow, endothelial injury and increased inflammation [26].

P. falciparum has been estimated to be older than 100,000 years resulting in an exquisite coadaption of both, the parasite and the human host $[68,117]$. Older children and adults residing in malaria-endemic countries usually develop over time naturally acquired immunity induced by repeated exposure, leading to decreasing disease severity with age [121]. Rodent and non-human primate animal models for malaria have provided essential insights into the biology of this parasite [177]. To date, no good immunological correlates of protection have been identified for malaria infection outcome or vaccination in humans [13]. It is generally accepted that studying malaria immunity in different human populations and age groups is essential for detailed understanding of this intricate host-pathogen interaction.

\section{Controlled human malaria infections}

By using controlled human malaria infections (CHMI), it is hoped to identify effector mechanisms and correlates of protection that could guide next-generation malaria vaccine development $[27,153]$. Human challenge models for malaria are defined as the intentional infection of adult volunteers with Plasmodium parasites under controlled conditions within a well-defined and restricted ethical framework (https://www. who.int/biologicals/expert_committee/Human_challenge Trials_IK_final.pdf). CHMI based on $P$. falciparum and $P$. vivax inoculations were used as early as in the beginning of the twentieth century to treat neurosyphilis known as malariotherapy, which was rewarded with the Noble Price in Physiology and Medicine in 1927 to Julius Wagner-Jauregg (https://www.nobelprize.org/prizes/medicine/1927/wagnerjauregg/lecture/). Since the 1980s, volunteers can be reproducibly infected by the bite of reared malaria-infected mosquitoes in several centres in the USA and Europe [25, 131]. With the advent of the development of sterile, purified, 
metabolically active, cryopreserved $P$. falciparum sporozoites by Sanaria Inc. that can be injected intradermally $[25,130$, 145], intramuscularly [74, 144] and intravenously [57, 113], the number of clinical trial centres able to perform malaria CHMI studies globally has expanded rapidly. This novel approach has been particularly essential for conducting clinical studies in malaria pre-exposed populations in sub-Saharan Africa $[60,73,87,88]$. Intravenous inoculation of parasitized erythrocytes infected with $P$. falciparum and $P$. vivax has added to the variety of CHMI approaches available for the scientific community $[61,122]$. CHMI models have played major roles in clinical vaccine and drug development [39, $140]$, testing and validation of diagnostic markers and tools $[34,142]$ and research in parasite biology $[8,9,75]$. CHMI studies allowed the description of impact of malaria preexposure [1, 91, 118], HIV, co-infections (https:// clinicaltrials.gov/ct2/show/NCT03420053) and haemoglobinopathies [101] on elicited immune responses. The main strength of CHMI relates to the defined infection timing, P. falciparum strain [23, 97] and inoculum dose and route chosen. In summary, CHMI enable the study of malaria immunity in different human populations representing an essential "human model" for this disease.

\section{T cells in human malaria immune responses}

T lymphocytes are key components of the immune system contributing to the anti-P. falciparum immunity and are of major interest in malaria research. The vast majority of studies dedicated to T cell-mediated immunity have focused on "conventional" adaptive $\mathrm{CD}^{+}$and $\mathrm{CD} 8^{+} \mathrm{T}$ cells $[31,95,96]$. Those cells express $\alpha \beta$ T cell receptors (TCR) that recognize peptide antigens presented by highly polymorphic major histocompatibility complex (MHC) class I and II molecules. Once activated, $\mathrm{CD} 4^{+}$and $\mathrm{CD} 8^{+} \mathrm{T}$ cells undergo clonal expansion and differentiation into special subsets with unique functions to orchestrate key aspects of innate and adaptive immunity during $P$. falciparum infections (reviewed in [96]). $\mathrm{CD}^{+} \mathrm{T}$ cells develop into cytotoxic $\mathrm{T}$ cells with the ability to target and kill mainly the Plasmodium-infected hepatocytes but not infected erythrocytes as they lack MHC class I expression. $\mathrm{CD} 4^{+} \mathrm{T}$ cell subsets provide help to $\mathrm{CD} 8^{+} \mathrm{T}$ cells, $\mathrm{B}$ cells and activation of antigen-presenting cells (APC) such as dendritic cells and macrophages $[95,96]$. Clinical trials to induce strong and durable anti-P. falciparum $\mathrm{T}$ cell responses by subunit and whole parasite vaccination approaches have yielded so far limited success, thought to be based on diversity of antigen expression during different development stages, heterogeneity in the $P$. falciparum strains and suboptimal vaccine formulations and delivery $[27,108]$. One of the barriers that needs to be overcome rests with the donor-specific, highly polymorphic MHC (human leucocyte antigen (HLA)) molecules presenting distinct peptide repertoires to diverse $\mathrm{T}$ cell populations $[42,43]$. In addition, DCs and macrophages were shown to fail in upregulating HLA-DR expression upon P. falciparum infection $[162,163]$ limiting their capacities to activate conventional antigen-specific T cells.

In contrast, unconventional T cells target highly conserved, monomorphic MHC class Ib and MHC-I like molecules and other ligands. These include unconventional $\alpha \beta$ T cells such as MAIT and NKT cells that are restricted to metabolitepresenting MHC class I-related proteins (MR1) and lipidpresenting cluster of differentiation 1 (CD1) molecules, respectively $[53,165]$. In addition, some $\gamma \delta \mathrm{T}$ cells can recognize MR1 and CD1 molecules, while the vast majority recognizes butyrophilin (BTN) and BTN-like (BTNL) proteins or stress-induced ligands $[36,53,80]$ allowing them to participate in health and diseases.

\section{Mucosal-associated invariant $\mathrm{T}$ cells}

MAIT cells are a special subset of MR1-restricted T cells carrying features of the innate immunity. They are present mainly in mucosal tissues, the liver and lymphoid tissues but also recirculate in peripheral blood $[114,158]$. The highest frequencies are found in liver and peripheral blood in which they represent up to $45 \%$ and $10 \%$ of T cells, respectively [44, $51,98,154]$, while they are less frequent in lymphoid tissues and comprise around only $1 \%$ of splenic $\alpha \beta$ T cells [158]. MAIT cells are characterized by the expression of the semiinvariant TCR composed of the $\mathrm{V} \alpha 7.2$ chain rearranged with $\mathrm{J} \alpha 33, \mathrm{~J} \alpha 12$ and $\mathrm{J} \alpha 20$, paired with a constrained TCR $\beta$ repertoire (enriched for TRBV6 and TRBV20-1) and high levels of surface expression of CD161 [102, 119, 125, 157]. They are restricted to MR1 [159] and depend on the presence of commensal microbiota and their metabolites for development and activation $[100,159]$. The canonical, activating MAIT cell antigens presented by MR1 were identified as ligands generated from precursors to riboflavin in the riboflavin synthesis pathway of bacteria and fungi [93]. Further characterization revealed the diverse nature of these antigens - they are derived from 5-amino-6-d-ribitylaminouracil (5-A-RU), an intermediate of the riboflavin biosynthesis pathway. 5-A-RU reacting with glyoxal or methylglyoxal leads to generation of potent MR 1-ligands 5-(2-oxoethylideneamino)-6-Dribitylaminouracil and 5-(2-oxopropylideneamino)-6-Dribitylaminouracil, respectively [28]. These antigens are instable in solution but get stabilized in the antigen-binding pocket of MR1 by formation of a Schiff base with lysine amino acid residue 43 [28]. This interaction possibly influences their potency, which is high compared with non-stabilized 6,7-dimethyl-8-D-ribityllumazine [107, 141]. Blood-derived MAIT cells respond to different antigens by distinct changes in the surface marker expression [107, 141]. Further studies 
showed the existence of a broader MR1 ligand repertoire including ligands derived from riboflavin-auxotroph bacteria [56, 67], mammalian cells [103] and drugs [92]. Some metabolites of folic acids such as 6-formylpterin (6-FP) and acetyl6-FP as well as bacterial ligands do bind to MR1 but act as antagonists $[45,67,93]$ suggesting that the function is modulated depending on the specific antigen-MR1 interaction. Therefore, MAIT cells are predominantly activated by cells infected with riboflavin-synthetizing bacteria and fungi, but not by uninfected or virus-infected cells [166]. In the absence of TCR engagement, MAIT cells can be activated by IL-12 and IL-18 resulting in IFN $\gamma$-and TNF $\alpha$ production [105, 166], an effect that is conserved across many CD161expressing T cells $[47,164]$. In summary, MAIT cells are rapidly responding innate-like $\mathrm{T}$ cells with a restricted TCR repertoire that recognize metabolite-derived antigens and show high responsiveness to pro-inflammatory cytokines.

Few reports have described a potential involvement of MAIT cells in malaria immunity. Tanzanian volunteers undergoing intradermal CHMI by purified P. falciparum sporozoites developed asexual blood-stage parasitaemia [116]. We examined the frequency of MAIT cells $\left(\mathrm{CD} 3^{+} \mathrm{V} \alpha 7.2^{+} \mathrm{CD} 161^{\mathrm{hi}}\right)$ on study days 0 and 9 post-infection and then after the malaria treatment on days 28,56 and 168 . Using a single-cell RNAseq approach, we found that the MAIT cell population displayed a distinct RNA expression profile suggesting that they responded to the malaria challenge by day 9 after sporozoite inoculation and did not return to baseline transcriptional status by day 28. Durable expansion of circulating $\mathrm{CD} 8^{+}$MAIT cells for several months after parasite infection might be possibly driven by homeostatic expansion [116]. In a follow-up study conducted in Tanzanian volunteers, ex vivo MAIT cell activation (upregulation of CD38) and expansion after asexual blood-stage parasitaemia were confirmed [137]. This data suggest that MAIT cells might contribute to immune responses, but the underlying molecular and cellular mechanism remains unknown. There are currently no defined antigens in P. falciparum known to be presented by MR1; MAIT expansion and activation could be indirectly driven by cytokines produced by activated APC.

Dendritic cells and monocytes/macrophages are known to produce IL-12 and IL-18 in response to danger- and pathogenassociated molecular patterns. Elevated pro-inflammatory cytokines including IL-12 and IL-18 have been detected in severe cases of malaria-infected individuals [94, 106], and IL-12 has been shown to be involved in cellular immune responses to blood-stage infections [32]. Indeed, in vitro MAIT cell proliferation and activation were induced by co-culture of infected red blood cells (iRBCs) with autologous DCs and PBMCs collected from these malaria pre-exposed volunteers [137]. MAIT cells from $P$. falciparum-infected humans were still responsive to IL-12, IL-15 and IL-18 activation and produced IFN $\gamma$, IL-17A and Granzyme B (grzB) [116] and did not succumb to malaria-induced immunosuppression [116]. Alternatively, activation of MAIT cells might be a consequence of impaired gut barrier integrity and function during malaria. Histopathological sections in severe malaria cases indicated intense adherence and sequestration of iRBC into the gut $[123,143]$ possibly resulting into gut tissue damage and microbial translocation, thus activating gut- and liverhoming MAIT cells.

Hence, MAIT cells are emerging as an unconventional T cell population involved and possibly contributing to antiP. falciparum T cell immunity.

\section{CD1-restricted T cells}

Humans express four CD1 antigen-presenting molecules, divided into two groups: CD1a, CD1b, CD1c (group 1) and CD1d (group 2) [53, 165]. CD1 molecules are MHC class Ilike molecules expressed on APCs, and they present distinct lipid-based antigens of a diverse origin [53, 165]. Group 1 $\mathrm{CD} 1$ molecules are differentially expressed in APCs with high expression of CD1a in skin-resident DCs and Langerhans cells, CD1b in myeloid DCs in lymphoid tissue and CD1c in DCs and B cells. In contrast, CD1d is widely expressed on many cells types including monocytes, B cells and epithelial cells $[53,165]$. CD1d-presented lipid antigens are recognized by the iNKT cell TCR comprised of an invariant $\mathrm{V} \alpha 24 \mathrm{~J} \alpha 18$ chain and a TCR $\beta$ chain of a limited repertoire $[53,165]$. iNKT cells recognize the model antigen $\alpha$ GalCer, and although many foreign lipids are recognized by these $\mathrm{T}$ cells, it is not clear whether NKT cells encounter them under nonexperimental conditions [17].

CD1c expression was increased on monocytes and inflammatory $\mathrm{CD} 16^{+} \mathrm{DC}$ during blood-stage infection in malaria naïve volunteers after CHMI [156] suggesting that CD1 molecules have the capacities to present $P$. falciparum or self-lipid antigens to CD1-restricted $\mathrm{T}$ cells. A comprehensive lipid analysis of asexual blood-stage $P$. falciparum profiled 300 lipids [64], which might - if presented by group 1 and/or 2 CD1 molecules - activate unconventional T cells in the liver or other organs. Moreover, as endogenous lipids presented by CD1 group 1 molecules can activate T cells [38], P. falciparum infection might have an influence on this subset of unconventional $\mathrm{T}$ cells.

Very few studies have addressed the role of CD1drestricted iNKT cells in human malaria infections, natural or experimental during CHMI. One study demonstrated that the proportion of blood-derived unconventional $\mathrm{T}$ cells with NK phenotype $\left(\mathrm{CD}^{+} \mathrm{CD}^{2} 6^{+}\right.$or $\left.\mathrm{CD} 3^{+} \mathrm{CD} 57^{+}\right)$is increased in malaria patients, especially in adults [169]. In contrast, a more recent study demonstrated that the frequency of invariant $\mathrm{CD}^{+} \mathrm{V} \alpha 24 \mathrm{~J} \alpha 18^{+}$NKT cells did not change significantly following controlled malaria infection in peripheral blood 
[116]. This might be due to the lack of stimulating CD1d antigens and/or lipid presentation during malaria in bloodstage infections but does not exclude iNKT cells from having an antiparasitic role and/or participating in anti-P. falciparum immunity in other organs such as the liver. In order to determine their anti-malaria potential, further studies should investigate CD1-restricted T cells in individuals experimentally challenged by CHMI or naturally infected in endemic areas.

\section{үठ T cells}

T cells, defined by their expression of the $\gamma \delta$ TCR, are a heterogeneous population of lymphocytes and are not limited to antigen presentation by MHC proteins, CD1 and MR1. They represent up to $5 \%$ of $\mathrm{T}$ cells in the lymphoid and nonlymphoid organs in humans [168]. Furthermore, the rapid activation of $\gamma \delta$ T cells [69] may critically regulate tissue immunogenicity by modulating the microenvironment so as to accommodate time-delayed adaptive responses of $\mathrm{B}$ cells and $\alpha \beta$ T cells [70] in response to infections and vaccines.

Human $\gamma \delta \mathrm{T}$ cells have a reduced number of $\mathrm{V}$ and $\mathrm{J}$ gene segments to select from during rearrangement, but $\gamma \delta \mathrm{TCR}$ diversity is largely achieved through extensive junctional diversity. The $\mathrm{V} \gamma$ chains mainly pair with $\mathrm{V} \delta 1, \mathrm{~V} \delta 2$ and $\mathrm{V} \delta 3$ chains although more $\delta$ chains exist [2]. Moreover, some $\mathrm{V} \gamma$ pseudogenes have been described in the $\gamma$ locus without "functional" rearrangement found so far in humans [2]. Interestingly, the length of the complementarity determining region 3 (CDR3) of the $\gamma \delta$ TCR is much less constrained compared to the $\alpha \beta$ TCR repertoire, especially the CDR3 of the TCR $\delta$ chain can be significantly longer. This is reminiscent of the CDR3 length distribution of antibodies, and it has been implied that $\gamma \delta$ T cells recognize antigen in an antibodylike manner [129]. The CDR3-driven ligand recognition allows the $\gamma \delta \mathrm{T}$ cell to interact with target cells in an MHCunrestricted manner [115] and therefore does not require expression of CD4 and CD8 coreceptor [90]. Knowledge of molecular mechanisms leading to $\gamma \delta$ TCR recognition of antigens and functional consequences for $\gamma \delta \mathrm{T}$ cell physiology remain scarce. $\gamma \delta$ TCRs might recognize and directly interact with several host-derived ligands expressed on the surface of human cells $[69,173]$. Various $\gamma \delta$ T cell subsets are modulated in their activation upon interactions with B7-like BTN and BTNL proteins [6]. Innate-like $\mathrm{V} \gamma 9 \mathrm{~V} \delta 2 \mathrm{~T}$ cells, highly present in peripheral blood, are activated by human cells expressing the BTN3A1 molecule, which is essential for binding phosphorylated antigens [139, 167]. A recent study further demonstrated that BTN2A1 is a direct ligand for the V $\gamma 9 \mathrm{~V} \delta 2$ TCR acting in unison with BTN3A1 to licence $\gamma \delta$ $\mathrm{T}$ cell responses to phosphorylated antigens [128]. Another study showed direct binding of human $\mathrm{V} \gamma 4^{+} \mathrm{TCR}$ to BTN3L resulting in $\mathrm{T}$ cells activation in a superantigen-like binding mode, while endothelial protein $\mathrm{C}$ receptor (EPCR) binds to V $\gamma 4 \mathrm{~V} \delta 5$ TCR in a CDR3-dependent and antibodylike binding mode that mediates adaptive immunity [175]. The non-V $82 \mathrm{~T}$ cells responsive to the autoantigen EPCR respond to CMV-infected fibroblast and endothelial cells by direct interactions of the TCR to the ligand and other costimulatory ligands [174]. Thus, for full activation, V $\delta 1 \mathrm{~T}$ cells might rely on integration of several signals, both TCRmediated and TCR-extrinsic. Other V $\delta 1 \mathrm{~T}$ cells have been shown to recognize phycoerythrin [179], monomorphic CD1 molecules presented on APCs $[10,135,148,161]$ and MR1 overexpressed in cell lines [99]. Because of low abundance of CD1-, MR1- and PE-recognizing $\gamma \delta \mathrm{T}$ cells in humans, it seems unlikely that these $\mathrm{V} \delta 1 \mathrm{~T}$ cells represent expanded effector V $\delta 1$ clonotypes in diseases such as malaria. There is evidence that $\gamma \delta$ T cells can get activated by cytokines in a TCR-extrinsic fashion $[49,50]$ increasing the possibilities of $\gamma \delta \mathrm{T}$ cells to participate in bridging innate and adaptive immune responses.

An important feature of $\gamma \delta \mathrm{T}$ cells is their capability to home to epithelial and mucosal surfaces [19]. In the liver, preferentially $\mathrm{V} \delta 1$ and $\mathrm{V} \delta 3 \mathrm{~T}$ cells are present with high diversity of the TCR repertoire after durable and subject-specific expansion [36, 37, 77]. Their physiological roles might include production of pro-inflammatory cytokines and growth factors to recruit immune cells, activate phagocytic cells and promote DC maturation [19] as well as tissue repair and regeneration [84]. $\gamma \delta \mathrm{T}$ cells are able to provide B cell help and present antigens to other $\mathrm{T}$ cell subsets further contributing to protection against infectious diseases, wound healing and epithelial cell maintenance [19].

A number of studies support the idea that $\gamma \delta \mathrm{T}$ cells are involved in immunity during $P$. falciparum infections. First, $\gamma \delta \mathrm{T}$ cells home to organs including skin, blood and liverbody sites which are preferentially exposed to $P$. falciparum parasites. Second, $\gamma \delta$ T cells expand upon $P$. falciparum infections in children and adults from malaria-endemic and nonendemic regions $[71,72,79,132,133,176]$. Third, $\gamma \delta \mathrm{T}$ cells express a broad range of effector cytokines including IFN $\gamma$ and $\mathrm{TNF} \alpha$ secretion and display cytotoxic activities in response to the parasite $[29,49,82]$.

The most abundant $\gamma \delta$ TCR expressed in humans is V $\delta 2$, preferentially paired with $\mathrm{V} \gamma 9$ [146], and these $\mathrm{T}$ cells proliferate extensively in malaria infections $[71,72,79,132,133$, 176]. During CHMI, but not repeated immunizations with live, purified, attenuated $P$. falciparum sporozoites delivered intravenously, expansion of V $82 \mathrm{~T}$ cells in individuals developing asexual blood-stage infections has been observed [71, 137] supporting previous observations that asexual bloodstage infections drive $\mathrm{V} \gamma 9 \mathrm{~V} \delta 2 \mathrm{~T}$ cells expansion. $\mathrm{V} \gamma 9 \mathrm{~V} \delta 2$ $\mathrm{T}$ cells likely respond to different stimuli expressed by infected RBC and merozoites [14, 41, 59, 81, 86, 104, 149, 170]. Further characterization of ligands revealed that stressed cells 
and $P$. falciparum produce phosphoantigens including isopentenyl pyrophosphate and E-4-hydroxy-3-methyl-but-2enyl pyrophosphate (HMBPP) with the capacity to activate V $\gamma 9 \mathrm{~V} 82$ T cells $[14,15,55]$. Recognition of phosphoantigens requires the expression of BTN3A and BTN2A molecules on target cells critical for $\mathrm{V} \gamma 9 \mathrm{~V} \delta 2 \mathrm{~T}$ cell activation $[66,127$, 167]. P. falciparum-infected RBC do not express butyrophilin 3 , and $\mathrm{V} \gamma 9 \mathrm{~V} \delta 2 \mathrm{~T}$ cell activation does not require direct cellto-cell contact involving TCR engagement [63].

Similarly, the mechanisms by which free merozoites are recognized by $\mathrm{V} \gamma 9 \mathrm{~V} \delta 2 \mathrm{~T}$ cells remain unknown [29]. One possible mechanism might be antibody-dependent cellular cytotoxicity, as $\mathrm{V} \gamma 9 \mathrm{~V} \delta 2 \mathrm{~T}$ cells can express the Fc receptor CD16 [5]. Dendritic cells and possibly other cell types might recognize iRBC and merozoites by presentation of self- or pathogen-derived phosphoantigens in context of by BTN3A/ BTN2A.

Despite their effector functions in malaria, $\mathrm{V} \gamma 9 \mathrm{~V} \delta 2 \mathrm{~T}$ cells are also known to express surface molecules with the potential to mediate immune regulation $[24,126]$. After CHMI in malaria pre-exposed volunteers, $\mathrm{V} \gamma 9 \mathrm{~V} \delta 2 \mathrm{~T}$ cells did not upregulate the programmed cell death 1 (PD1) and lymphocyteactivation gene 3 [137]. This data suggested either the lack of sufficient TCR stimulation or differences in the kinetic of $\gamma \delta \mathrm{T}$ cells in peripheral blood after CHMI, as zolodronate induced activation of $\mathrm{V} \gamma 9 \mathrm{~V} \delta 2 \mathrm{~T}$ cells induced PD-1 expression in vitro [76]. In addition to the production of proinflammatory cytokines such as TNF $\alpha, \operatorname{IFN} \gamma$ and cytotoxic mediators including granulysin [33, 82], V $\gamma 9 \mathrm{~V} \delta 2 \mathrm{~T}$ cells can produce GM-CSF [81] and might thereby influence monocyte differentiation into DCs and recruitment of other immune cells including T cells [147]. Overall, the data suggests that innatelike $\mathrm{V} \gamma 9 \mathrm{~V} \delta 2 \mathrm{~T}$ cells might participate in anti-malaria immunity in various ways.

In contrast, adaptive-like V $\delta 1 \mathrm{~T}$ cells are highly abundant in peripheral epithelial tissues including skin, gut and liver $[20,40,65,77]$. In the liver, V $\delta 1 \mathrm{~T}$ cells represent the largest population of $\gamma \delta$ T cells with unique characteristics indicative for resident and circulating T cells [77]. Early work published in the 1990s indicated an increased frequency of V $\delta 1 \mathrm{~T}$ cells circulating in peripheral blood of healthy individuals living in a malaria-endemic region in Ghana as well as a rapid but transient expansion of $\mathrm{V} \delta 1 \mathrm{~T}$ cells upon malaria chemotherapy in children [78, 79]. Further studies showed that V $\delta 1 \mathrm{~T}$ cells and other non-V $\delta 1 \mathrm{~T}$ cell subsets were expanded in malaria children and/or adults in Thailand, Ethiopia and Laos $[72,155,176]$. V $\gamma 2,3,4$ were the most common chains among expanded V $\delta 1 \mathrm{~T}$ cells, and the diverse usage of TCR $\gamma$ chains indicated a polyclonal response of $\mathrm{V} \delta 1$ and $\mathrm{V} \delta \mathrm{x} T$ cells from malaria-exposed individuals $[79,155]$. Length spectra-typing of the CDR3 $\delta$ of these V $\delta 1$ T cells did not reveal a dominant public clonotype to be expanded across all patients in a crosssectional analysis [79]. Recent data suggested that non-V $\delta 2$ and $\mathrm{V} \gamma 9-\mathrm{V} \delta 2+\mathrm{T}$ cell subsets seem to have an unfocused, highly diverse and donor-specific TCR repertoire as in naïve V $\delta 1$ T cells [35-37, 77, 124]. Clonal selection of naïve V $\delta 1 \mathrm{~T}$ cells that might respond to microbial/nonmicrobial stress upon infection might be the main driver of T cell expansion. Indeed, a proportion of $\mathrm{V} \delta 1 \mathrm{~T}$ cells expanded oligoclonally and displayed a unique signature of surface molecules in individuals from malaria-endemic regions [137]. Expansion and phenotypic differentiation of $\mathrm{V} \delta 1 \mathrm{~T}$ cells were only present in individuals with asexual blood-stage infections [136]. Clonal expansion of V $\delta 1 \mathrm{~T}$ cells was shown to be associated with differentiation from naïve $\mathrm{CD} 27^{+} \mathrm{T}$ cells into long-lived effector $\mathrm{CD} 27^{-} \mathrm{T}$ cells with phenotypical and functional changes. These $\mathrm{T}$ cells displayed an effector phenotype based on low expression of CD27, CCR7, CD28, IL-7R and CD62L as well as rapid activation and proliferation in response to TCR signalling [35]. In line with these observations, activated V $\delta 1 \mathrm{~T}$ cells had low expression of CD27, lacked CD57 indicating activation and differentiation from naïve $\mathrm{CCR} 7^{+} \mathrm{V} \delta 1 \mathrm{~T}$ cells into early effector CCR7 $7^{-} \mathrm{V} \delta 1 \mathrm{~T}$ cells [137]. Further phenotypic characterization of these expanding $\mathrm{V} \delta 1 \mathrm{~T}$ cells revealed a distinct pattern by co-expressing CD38 and PD1 which is distinct from other unconventional $\mathrm{T}$ cells. These molecules are associated with an exhausted phenotype in $\mathrm{CD} 4^{+} \mathrm{T}$ cells during malaria infection [21] and might influence $\mathrm{V} \delta 1 \mathrm{~T}$ cell function by modulating inflammatory cytokines production and cytotoxicity during liver- and blood-stage infections. The diversity in expression of a range of surface markers points towards a so far unappreciated heterogeneity in $\mathrm{V} \delta 1$ $\mathrm{T}$ cell responses $[20,40,65,77,137]$. V $\delta 1 \mathrm{~T}$ cells produced selectively ex vivo IFN $\gamma$ in response to hepatocyte-derived cell lines [7, 46, 48, 124]. Whether circulating asexual blood-stage parasites represent an immune stimulus for liver resident $\mathrm{V} \delta 1 \mathrm{~T}$ cells resulting in clonal expansion remain to be investigated. It has been shown that established clonotypes are long-lived and persist for several months to years in human peripheral blood $[35,124]$. A population of $\mathrm{V} \delta 1 \mathrm{~T}$ cells, characterized by the expression of CD38 and PD1, displayed durable expansion of clonally distinct T cells after CHMI [137]. Studying the TCR repertoire of V $\delta 1 \mathrm{~T}$ cells and characterization of expanded clonotypes are essential steps to determine how V $\delta 1 \mathrm{~T}$ cells actually respond to malaria.

So far, few $\gamma \delta$ TCR ligands have been identified, and there is no evidence that $\mathrm{V} \delta 1 \mathrm{~T}$ cells recognize directly asexual blood-stage parasites [58, 72], which is in line with our observation that $\mathrm{V} \delta 1 \mathrm{~T}$ cell expansion depended on the presence of iRBC and autologous DCs [137]. Expansion of V $\delta 1 \mathrm{~T}$ cell clones might have been facilitated by cytokines produced by monocyte-derived DC, monocytes or activated non-V $\delta 1$ cells in PBMCs [137]. Indeed, IL-15 produced by activated monocytes, fibroblasts and epithelial cells [152] and hepatocyte cell lines [134] might promote activation and proliferation of $\gamma \delta \mathrm{T}$ cells. In addition, P. falciparum-activated non-V $\delta 1 \mathrm{~T}$ cells 
might produce IL-2 contributing to the observed response ex vivo.

The massive polyclonal $\mathrm{B}$ cell activation during malaria infections might lead to subsequent reactivation of CMV and Epstein-Barr virus (EBV) and further B cells proliferation, which might in turn induce $\mathrm{V} \delta 1 \mathrm{~T}$ cell proliferation [80]. It might be of interest to screen volunteers involved in malaria immunity studies for pre-existing viral co-infections like CMV and EBV which might impact indirectly on type and size of ensuing $\gamma \delta$ T cell activation after malaria infection.

Interestingly, a $\mathrm{V} \delta \mathrm{x} \mathrm{T}$ cell clone expressing a $\mathrm{V} \gamma 4 \mathrm{~V} \delta 5$ TCR can recognize EPCR [174]. EPCR is present on many different cells in various organs such as liver and blood vessels [52] and can bind lipids such as phosphatidylcholine or lysophosphatidylcholine and platelet-activating factor [112]. This $\gamma \delta$ TCR engages with EPCR when the intercellular adhesion molecule 1 (ICAM-1) is co-expressed, but this interaction is independent of displayed lipids. In malaria, $P$. falciparum erythrocyte membrane protein 1 expressed on $\mathrm{iRBC}$ binds to EPCR with increased binding of parasites isolated from patients suffering from severe malaria [160]. Therefore, EPCR might represent a molecule displaying stress such as viral infections and other stress conditions. Whether asexual blood-stage infections represent such stress stimuli and modulate EPCR expression and subsequent TCRmediated $\mathrm{T}$ cell activation remains open. Clearly, identification of ligands recognized by $\mathrm{V} \delta 1$ and $\mathrm{V} \delta \mathrm{x} \mathrm{T}$ cells during malaria will provide a more comprehensive understanding of $\gamma \delta$ TCR ligand activation.

\section{Summary}

Cell-mediated immune responses are critical for anti$P$. falciparum immunity. It has long been recognized that unconventional T cells, especially $\gamma \delta \mathrm{T}$ cells, respond to asexual blood-stage infections. The fact that MAIT and $\gamma \delta$ $\mathrm{T}$ cell frequencies and selective clonotypes expand during asexual blood-stage infections suggests that these cells have a role in malaria immunity. While innate-like $\mathrm{T}$ cells including $\mathrm{V} \gamma 9 \mathrm{~V} \delta 2$, NKT and MAIT cells have the ability to rapidly respond and elicit effector functions without clonal expansion and differentiation, $\mathrm{V} \delta 1$ and $\mathrm{V} \delta \mathrm{x}$ T cells display more features of adaptive-like $\mathrm{T}$ cells. Unconventional $\mathrm{T}$ cells home to non-lymphoid tissue sites such as skin, liver, spleen and gut, which are key tissues in the context of malaria infections. The involvement of other unconventional $\mathrm{T}$ cells restricted to non-polymorphic antigen presenting molecules like HLA-E, HLA-G and CD1 in malaria immunity remains to be defined. The incorporation of innate-like and adaptive-like unconventional T cells into research studies has the potential to provide novel approaches for vaccine development and immunotherapy in malaria.

\section{Concluding remarks and outlook}

In malaria research, unconventional $\mathrm{T}$ cells gain growing attention due to their diverse and specific functions in bridging innate and adaptive immunity. Unconventional innate-like $\mathrm{T}$ cells respond rapidly to infections and stress-induced signals and have the capacity to become $\mathrm{T}$ cell populations with tissue-resident and/or circulating features. Therefore, targeting these cell populations might provide an opportunity to increase efficacy of currently pursued experimental vaccine approaches. To unravel mechanisms of protection or participation in pre-erythrocytic anti- $P$. falciparum immunity, getting access to liver biopsies for characterization of liver residing $\mathrm{T}$ cells at the single-cell level is essential. Technological advances for improved gene coverages and simultaneous characterization of the TCR by scRNA-seq have become available. These approaches will help to understand the intrinsic heterogeneity among antigen-specific T cells and their tissuespecific roles in malaria. V $\delta 1 \mathrm{~T}$ cells recognize stress-induced molecules and respond to cytokines induced by viruses, and therefore investigating viral co-infections in volunteers undergoing CHMI might provide new insights into the well-known heterogeneity of anti-malaria immunity. Futhermore, the microbiome has been shown to impact communicable and non-communicable diseases, and certain intestinal communities might even promote protection against $P$. falciparum infections. Inclusion of microbiome studies in future field trials might unravel important new mechanisms driven by the interaction with unconventional T cells. CHMI studies can now be conducted safely in more clinical research centres than ever before in the field of malaria. This opens exiting new possibilities to address critical knowledge gaps in different human populations with several degrees of malaria pre-exposure, genetic background and co-infection status.

What are unappreciated ligands and stimuli of nonV $\gamma 9 \mathrm{~V} \delta 2$ T cells, MAIT cells and NKT cell subsets in human malaria?

Are unconventional T cells stage specific in malaria immunity and do they develop memory?

Does malaria induce tissue-specific metabolic changes that can be sensed by unconventional T cells?

Which micro-environmental changes are induced by the long-lasting clonal expansion of unconventional T cells after asexual blood-stage infections?

Do chronic malaria infections promote dysregulation of unconventional $\mathrm{T}$ cells leading to variations of clinical outcomes?

How do unconventional T cells communicate with innate immune cells and conventional lymphocytes? 
Acknowledgements We thank Marcel Tanner for his tireless effort to control malaria worldwide. We thank the study participants and the entire study team at the Bagamoyo branch of the Ifakara Health Institute and the teams at Sanaria and Protein Potential for the establishment of CHMI in Tanzania.

Funding information This work was supported by the Swiss Vaccine Research Institute, Switzerland, and the Equatorial Guinea Malaria Vaccine Initiative.

\section{Compliance with ethical standards}

Conflict of interest The authors declare that they have no conflict of interest.

\section{References}

1. Achan J, Reuling I, Yap XZ et al (2019) Serologic markers of previous malaria exposure and functional antibodies inhibiting parasite growth are associated with parasite kinetics following a Plasmodium falciparum controlled human infection. Clin Infect Dis

2. Adams EJ, Gu S, Luoma AM (2015) Human gamma delta T cells: evolution and ligand recognition. Cell Immunol 296:31-40

3. Aguilar R, Magallon-Tejada A, Achtman AH et al (2014) Molecular evidence for the localization of Plasmodium falciparum immature gametocytes in bone marrow. Blood 123:959-966

4. Aly AS, Vaughan AM, Kappe SH (2009) Malaria parasite development in the mosquito and infection of the mammalian host. Annu Rev Microbiol 63:195-221

5. Angelini DF, Borsellino G, Poupot M, Diamantini A, Poupot R, Bernardi G, Poccia F, Fournié JJ, Battistini L (2004) FcgammaRIII discriminates between 2 subsets of Vgamma9Vdelta2 effector cells with different responses and activation pathways. Blood 104:1801-1807

6. Arnett HA, Viney JL (2014) Immune modulation by butyrophilins. Nat Rev Immunol 14:559-569

7. Autran B, Triebel F, Katlama C et al (1989) T cell receptor gamma/ delta+ lymphocyte subsets during HIV infection. Clin Exp Immunol 75:206-210

8. Bachmann A, Petter M, Krumkamp R et al (2016) Mosquito passage dramatically changes var gene expression in controlled human Plasmodium falciparum infections. PLoS Pathog 12: e1005538

9. Bachmann A, Bruske E, Krumkamp R et al (2019) Controlled human malaria infection with Plasmodium falciparum demonstrates impact of naturally acquired immunity on virulence gene expression. PLoS Pathog 15:e1007906

10. Bai L, Picard D, Anderson B et al (2012) The majority of CD1dsulfatide-specific $\mathrm{T}$ cells in human blood use a semiinvariant Vdelta1 TCR. Eur J Immunol 42:2505-2510

11. Bannister L, Mitchell G (2003) The ins, outs and roundabouts of malaria. Trends Parasitol 19:209-213

12. Baton LA, Ranford-Cartwright LC (2005) How do malaria ookinetes cross the mosquito midgut wall? Trends Parasitol 21: 22-28

13. Beeson JG, Kurtovic L, Dobano C et al (2019) Challenges and strategies for developing efficacious and long-lasting malaria vaccines. Sci Transl Med 11

14. Behr C, Dubois P (1992) Preferential expansion of V gamma 9 V delta $2 \mathrm{~T}$ cells following stimulation of peripheral blood lymphocytes with extracts of Plasmodium falciparum. Int Immunol 4: 361-366
15. Behr C, Poupot R, Peyrat MA, Poquet Y, Constant P, Dubois P, Bonneville M, Fournie JJ (1996) Plasmodium falciparum stimuli for human gammadelta $T$ cells are related to phosphorylated antigens of mycobacteria. Infect Immun 64:2892-2896

16. Beier JC, Davis JR, Vaughan JA, Noden BH, Beier MS (1991) Quantitation of Plasmodium falciparum sporozoites transmitted in vitro by experimentally infected Anopheles gambiae and Anopheles stephensi. Am J Trop Med Hyg 44:564-570

17. Berzins SP, Ritchie DS (2014) Natural killer T cells: drivers or passengers in preventing human disease? Nat Rev Immunol 14: 640-646

18. Billker O, Lindo V, Panico M, Etienne AE, Paxton T, Dell A, Rogers M, Sinden RE, Morris HR (1998) Identification of xanthurenic acid as the putative inducer of malaria development in the mosquito. Nature 392:289-292

19. Bonneville M, O'brien RL, Born WK (2010) Gammadelta T cell effector functions: a blend of innate programming and acquired plasticity. Nat Rev Immunol 10:467-478

20. Bos JD, Teunissen MB, Cairo I, Krieg SR, Kapsenberg ML, Das PK, Borst J (1990) T-cell receptor gamma delta bearing cells in normal human skin. J Investig Dermatol 94:37-42

21. Butler NS, Moebius J, Pewe LL, Traore B, Doumbo OK, Tygrett LT, Waldschmidt TJ, Crompton PD, Harty JT (2011) Therapeutic blockade of PD-L1 and LAG-3 rapidly clears established bloodstage Plasmodium infection. Nat Immunol 13:188-195

22. Cerami C, Frevert U, Sinnis P et al (1992) The basolateral domain of the hepatocyte plasma membrane bears receptors for the circumsporozoite protein of Plasmodium falciparum sporozoites. Cell 70:1021-1033

23. Chattopadhyay R, Pratt D (2017) Role of controlled human malaria infection (CHMI) in malaria vaccine development: a U.S. food \& drug administration (FDA) perspective. Vaccine 35: 2767-2769

24. Chien YH, Meyer C, Bonneville M (2014) Gammadelta T cells: first line of defense and beyond. Annu Rev Immunol 32:121-155

25. Chulay JD, Schneider I, Cosgriff TM, Hoffman SL, Ballou WR, Quakyi IA, Carter R, Trosper JH, Hockmeyer WT (1986) Malaria transmitted to humans by mosquitoes infected from cultured Plasmodium falciparum. Am J Trop Med Hyg 35:66-68

26. Coban C, Lee MSJ, Ishii KJ (2018) Tissue-specific immunopathology during malaria infection. Nat Rev Immunol 18:266-278

27. Cockburn IA, Seder RA (2018) Malaria prevention: from immunological concepts to effective vaccines and protective antibodies. Nat Immunol 19:1199-1211

28. Corbett AJ, Eckle SB, Birkinshaw RW et al (2014) T-cell activation by transitory neo-antigens derived from distinct microbial pathways. Nature 509:361-365

29. Costa G, Loizon S, Guenot M et al (2011) Control of Plasmodium falciparum erythrocytic cycle: gammadelta $\mathrm{T}$ cells target the red blood cell-invasive merozoites. Blood 118:6952-6962

30. Cowman AF, Healer J, Marapana D, Marsh K (2016) Malaria: biology and disease. Cell 167:610-624

31. Crompton PD, Moebius J, Portugal S, Waisberg M, Hart G, Garver LS, Miller LH, Barillas-Mury C, Pierce SK (2014) Malaria immunity in man and mosquito: insights into unsolved mysteries of a deadly infectious disease. Annu Rev Immunol 32: $157-187$

32. Crutcher JM, Stevenson MM, Sedegah M, Hoffman SL (1995) Interleukin-12 and malaria. Res Immunol 146:552-559

33. Dantzler KW, Jagannathan P (2018) $\gamma \delta \mathrm{T}$ cells in antimalarial immunity: new insights into their diverse functions in protection and tolerance. 9

34. Das S, Jang IK, Barney B, Peck R, Rek JC, Arinaitwe E, Adrama $H$, Murphy $M$, Imwong $M$, Ling $C L$, Proux $S$, Haohankhunnatham W, Rist M, Seilie AM, Hanron A, Daza G, Chang M, Nakamura T, Kalnoky M, Labarre P, Murphy SC, 
McCarthy J, Nosten F, Greenhouse B, Allauzen S, Domingo GJ (2017) Performance of a high-sensitivity rapid diagnostic test for Plasmodium falciparum malaria in asymptomatic individuals from Uganda and Myanmar and naive human challenge infections. Am J Trop Med Hyg 97:1540-1550

35. Davey MS, Willcox CR, Joyce SP et al (2017) Clonal selection in the human Vdelta1 $\mathrm{T}$ cell repertoire indicates gammadelta TCRdependent adaptive immune surveillance. Nat Commun 8:14760

36. Davey MS, Willcox CR, Baker AT, Hunter S, Willcox BE (2018) Recasting human Vdelta1 lymphocytes in an adaptive role. Trends Immunol 39:446-459

37. Davey MS, Willcox CR, Hunter S et al (2018) The human Vdelta2(+) T-cell compartment comprises distinct innate-like Vgamma9(+) and adaptive Vgamma9(-) subsets. Nat Commun 9:1760

38. De Jong A, Cheng TY, Huang S et al (2014) CD1a-autoreactive T cells recognize natural skin oils that function as headless antigens. Nat Immunol 15:177-185

39. Dejon-Agobe JC, Ateba-Ngoa U, Lalremruata A et al (2019) Controlled human malaria infection of healthy adults with lifelong malaria exposure to assess safety, immunogenicity, and efficacy of the asexual blood stage malaria vaccine candidate GMZ2. Clin Infect Dis 69:1377-1384

40. Deusch K, Luling F, Reich K et al (1991) A major fraction of human intraepithelial lymphocytes simultaneously expresses the gamma/delta $\mathrm{T}$ cell receptor, the CD8 accessory molecule and preferentially uses the $\mathrm{V}$ delta 1 gene segment. Eur J Immunol 21:1053-1059

41. D'ombrain MC, Hansen DS, Simpson KM et al (2007) Gammadelta-T cells expressing NK receptors predominate over NK cells and conventional $\mathrm{T}$ cells in the innate IFN-gamma response to Plasmodium falciparum malaria. Eur J Immunol 37: 1864-1873

42. Doolan DL, Hoffman SL, Southwood S, Wentworth PA, Sidney J, Chesnut RW, Keogh E, Appella E, Nutman TB, Lal AA, Gordon DM, Oloo A, Sette A (1997) Degenerate cytotoxic T cell epitopes from P. falciparum restricted by multiple HLA-A and HLA-B supertype alleles. Immunity 7:97-112

43. Doolan DL, Southwood S, Chesnut R et al (2000) HLA-DRpromiscuous $\mathrm{T}$ cell epitopes from Plasmodium falciparum preerythrocytic-stage antigens restricted by multiple HLA class II alleles. J Immunol 165:1123-1137

44. Dusseaux M, Martin E, Serriari N et al (2011) Human MAIT cells are xenobiotic-resistant, tissue-targeted, CD161hi IL-17-secreting T cells. Blood 117:1250-1259

45. Eckle SB, Birkinshaw RW, Kostenko L, Corbett AJ, McWilliam H, Reantragoon R, Chen Z, Gherardin NA, Beddoe T, Liu L, Patel O, Meehan B, Fairlie DP, Villadangos JA, Godfrey DI, KjerNielsen L, McCluskey J, Rossjohn J (2014) A molecular basis underpinning the $\mathrm{T}$ cell receptor heterogeneity of mucosalassociated invariant T cells. J Exp Med 211:1585-1600

46. Farnault L, Gertner-Dardenne J, Gondois-Rey F, Michel G, Chambost H, Hirsch I, Olive D (2013) Clinical evidence implicating gamma-delta $\mathrm{T}$ cells in EBV control following cord blood transplantation. Bone Marrow Transplant 48:1478-1479

47. Fergusson JR, Smith KE, Fleming VM et al (2014) CD161 defines a transcriptional and functional phenotype across distinct human $\mathrm{T}$ cell lineages. Cell Rep 9:1075-1088

48. Fujishima N, Hirokawa M, Fujishima M, Yamashita J, Saitoh H, Ichikawa Y, Horiuchi T, Kawabata Y, Sawada KI (2007) Skewed $\mathrm{T}$ cell receptor repertoire of Vdelta1(+) gammadelta T lymphocytes after human allogeneic haematopoietic stem cell transplantation and the potential role for Epstein-Barr virus-infected B cells in clonal restriction. Clin Exp Immunol 149:70-79
49. Garcia VE, Jullien D, Song M et al (1998) IL-15 enhances the response of human gamma delta $\mathrm{T}$ cells to nonpeptide [correction of nonpetide] microbial antigens. J Immunol 160:4322-4329

50. Garcia VE, Uyemura K, Sieling PA et al (1999) IL-18 promotes type 1 cytokine production from NK cells and T cells in human intracellular infection. J Immunol 162:6114-6121

51. Gherardin NA, Souter MN, Koay HF, Mangas KM, Seemann T, Stinear TP, Eckle SB, Berzins SP, d'Udekem Y, Konstantinov IE, Fairlie DP, Ritchie DS, Neeson PJ, Pellicci DG, Uldrich AP, McCluskey J, Godfrey DI (2018) Human blood MAIT cell subsets defined using MR1 tetramers. Immunol Cell Biol 96:507-525

52. Gleeson EM, O'donnell JS, Preston RJ (2012) The endothelial cell protein $\mathrm{C}$ receptor: cell surface conductor of cytoprotective coagulation factor signaling. Cell Mol Life Sci 69:717-726

53. Godfrey DI, Uldrich AP, Mccluskey J et al (2015) The burgeoning family of unconventional T cells. Nat Immunol 16:1114-1123

54. Goel S, Palmkvist M, Moll K, Joannin N, Lara P, Akhouri RR, Moradi N, Öjemalm K, Westman M, Angeletti D, Kjellin H, Lehtiö J, Blixt O, Ideström L, Gahmberg CG, Storry JR, Hult AK, Olsson ML, von Heijne G, Nilsson I, Wahlgren M (2015) RIFINs are adhesins implicated in severe Plasmodium falciparum malaria. Nat Med 21:314-317

55. Goerlich R, Hacker G, Pfeffer K et al (1991) Plasmodium falciparum merozoites primarily stimulate the $\mathrm{V}$ gamma 9 subset of human gamma/delta T cells. Eur J Immunol 21:2613-2616

56. Gold MC, Mclaren JE, Reistetter JA et al (2014) MR1-restricted MAIT cells display ligand discrimination and pathogen selectivity through distinct T cell receptor usage. J Exp Med 211:1601-1610

57. Gomez-Perez GP, Legarda A, Munoz J et al (2015) Controlled human malaria infection by intramuscular and direct venous inoculation of cryopreserved Plasmodium falciparum sporozoites in malaria-naive volunteers: effect of injection volume and dose on infectivity rates. Malar J 14:306

58. Goodier M, Krause-Jauer M, Sanni A, Massougbodji A, Sadeler BC, Mitchell GH, Modolell M, Eichmann K, Langhorne J (1993) Gamma delta T cells in the peripheral blood of individuals from an area of holoendemic Plasmodium falciparum transmission. Trans R Soc Trop Med Hyg 87:692-696

59. Goodier MR, Lundqvist C, Hammarstrom ML et al (1995) Cytokine profiles for human V gamma 9+ T cells stimulated by Plasmodium falciparum. Parasite Immunol 17:413-423

60. Gordon SB, Rylance J, Luck A et al (2017) A framework for controlled human infection model (CHIM) studies in Malawi: report of a Wellcome Trust workshop on CHIM in low income countries held in Blantyre, Malawi. Wellcome Open Res 2:70

61. Griffin P, Pasay C, Elliott S et al (2016) Safety and reproducibility of a clinical trial system using induced blood stage Plasmodium vivax infection and its potential as a model to evaluate malaria transmission. PLoS Negl Trop Dis 10:e0005139

62. Gueirard P, Tavares J, Thiberge S, Bernex F, Ishino T, Milon G, Franke-Fayard B, Janse CJ, Ménard R, Amino R (2010) Development of the malaria parasite in the skin of the mammalian host. Proc Natl Acad Sci U S A 107:18640-18645

63. Guenot M, Loizon S, Howard J, Costa G, Baker DA, Mohabeer SY, Troye-Blomberg M, Moreau JF, Déchanet-Merville J, Mercereau-Puijalon O, Mamani-Matsuda M, Behr C (2015) Phosphoantigen burst upon Plasmodium falciparum Schizont rupture can distantly activate Vgamma9Vdelta2 T cells. Infect Immun 83:3816-3824

64. Gulati S, Ekland EH, Ruggles KV, Chan RB, Jayabalasingham B, Zhou B, Mantel PY, Lee MC, Spottiswoode N, Coburn-Flynn O, Hjelmqvist D, Worgall TS, Marti M, di Paolo G, Fidock DA (2015) Profiling the essential nature of lipid metabolism in asexual blood and gametocyte stages of Plasmodium falciparum. Cell Host Microbe 18:371-381 
65. Halstensen TS, Scott H, Brandtzaeg P (1989) Intraepithelial T cells of the TcR gamma/delta+ CD8- and V delta 1/J delta 1+ phenotypes are increased in coeliac disease. Scand J Immunol 30:665672

66. Harly C, Guillaume Y, Nedellec S, Peigné CM, Mönkkönen H, Mönkkönen J, Li J, Kuball J, Adams EJ, Netzer S, DéchanetMerville J, Léger A, Herrmann T, Breathnach R, Olive D, Bonneville M, Scotet E (2012) Key implication of CD277/ butyrophilin-3 (BTN3A) in cellular stress sensing by a major human gammadelta T-cell subset. Blood 120:2269-2279

67. Harriff MJ, Mcmurtrey C, Froyd CA et al (2018) MR1 displays the microbial metabolome driving selective MR1-restricted T cell receptor usage. Sci Immunol 3

68. Hartl DL (2004) The origin of malaria: mixed messages from genetic diversity. Nat Rev Microbiol 2:15-22

69. Hayday AC (2009) Gammadelta T cells and the lymphoid stresssurveillance response. Immunity 31:184-196

70. Hayday AC (2019) Gammadelta T cell update: adaptate orchestrators of immune surveillance. J Immunol 203:311-320

71. Ho M, Webster HK, Tongtawe P, Pattanapanyasat K, Weidanz WP (1990) Increased gamma delta T cells in acute Plasmodium falciparum malaria. Immunol Lett 25:139-141

72. Ho M, Tongtawe P, Kriangkum J, Wimonwattrawatee T, Pattanapanyasat K, Bryant L, Shafiq J, Suntharsamai P, Looareesuwan S, Webster HK, Elliott JF (1994) Polyclonal expansion of peripheral gamma delta T cells in human Plasmodium falciparum malaria. Infect Immun 62:855-862

73. Hodgson SH, Juma E, Salim A et al (2014) Evaluating controlled human malaria infection in Kenyan adults with varying degrees of prior exposure to Plasmodium falciparum using sporozoites administered by intramuscular injection. Front Microbiol 5:686

74. Hodgson SH, Juma E, Salim A et al (2015) Lessons learnt from the first controlled human malaria infection study conducted in Nairobi, Kenya. Malar J 14:182

75. Hoo R, Bruske E, Dimonte S, Zhu L, Mordmüller B, Sim BKL, Kremsner PG, Hoffman SL, Bozdech Z, Frank M, Preiser PR (2019) Transcriptome profiling reveals functional variation in Plasmodium falciparum parasites from controlled human malaria infection studies. EBioMedicine 48:442-452

76. Hsu H, Boudova S, Mvula G et al (2016) Prolonged PD1 expression on neonatal Vdelta2 lymphocytes dampens proinflammatory responses: role of epigenetic regulation. J Immunol 197:18841892

77. Hunter S, Willcox CR, Davey MS et al (2018) Human liver infiltrating gammadelta $\mathrm{T}$ cells are composed of clonally expanded circulating and tissue-resident populations. J Hepatol 69:654-665

78. Hviid L, Akanmori BD, Loizon S, Kurtzhals JA, Ricke CH, Lim A, Koram KA, Nkrumah FK, Mercereau-Puijalon O, Behr C (2000) High frequency of circulating gamma delta $\mathrm{T}$ cells with dominance of the $\mathrm{V}$ (delta) 1 subset in a healthy population. Int Immunol 12:797-805

79. Hviid L, Kurtzhals JA, Adabayeri V, Loizon S, Kemp K, Goka BQ, Lim A, Mercereau-Puijalon O, Akanmori BD, Behr C (2001) Perturbation and proinflammatory type activation of $\mathrm{V}$ delta 1(+) gamma delta $\mathrm{T}$ cells in African children with Plasmodium falciparum malaria. Infect Immun 69:3190-3196

80. Hviid L, Smith-Togobo C, Willcox BE (2019) Human Vdelta1(+) $\mathrm{T}$ cells in the immune response to Plasmodium falciparum infection. Front Immunol 10:259

81. Jagannathan P, Kim CC, Greenhouse B et al (2014) Loss and dysfunction of Vdelta2(+) gammadelta $\mathrm{T}$ cells are associated with clinical tolerance to malaria. Sci Transl Med 6:251ra117

82. Jagannathan P, Lutwama F, Boyle MJ et al (2017) Vdelta2+ T cell response to malaria correlates with protection from infection but is attenuated with repeated exposure. Sci Rep 7:11487
83. Jakeman GN, Saul A, Hogarth WL et al (1999) Anaemia of acute malaria infections in non-immune patients primarily results from destruction of uninfected erythrocytes. Parasitology 119(Pt 2): $127-133$

84. Jameson J, Ugarte K, Chen N, Yachi P, Fuchs E, Boismenu R, Havran WL (2002) A role for skin gammadelta T cells in wound repair. Science 296:747-749

85. Joice R, Nilsson SK, Montgomery J et al (2014) Plasmodium falciparum transmission stages accumulate in the human bone marrow. Sci Transl Med 6:244re245

86. Jones SM, Goodier MR, Langhorne J (1996) The response of gamma delta $\mathrm{T}$ cells to Plasmodium falciparum is dependent on activated CD4+ T cells and the recognition of MHC class I molecules. Immunology 89:405-412

87. Jongo SA, Church LWP, Mtoro AT et al (2019) Increase of dose associated with decrease in protection against controlled human malaria infection by PfSPZ vaccine in Tanzanian adults. Clin Infect Dis

88. Jongo SA, Church LWP, Mtoro AT, Chakravarty S, Ruben AJ, Swanson PA, Kassim KR, Mpina M, Tumbo AM, Milando FA, Qassim M, Juma OA, Bakari BM, Simon B, James ER, Abebe Y, Kc N, Saverino E, Gondwe L, Studer F, Fink M, Cosi G, elKhorazaty J, Styers D, Seder RA, Schindler T, Billingsley PF, Daubenberger C, Sim BKL, Tanner M, Richie TL, Abdulla S, Hoffman SL (2019) Safety and differential antibody and T-cell responses to the Plasmodium falciparum sporozoite malaria vaccine, PfSPZ vaccine, by age in Tanzanian adults, adolescents, children, and infants. Am J Trop Med Hyg 100:1433-1444

89. Josling GA, Llinas M (2015) Sexual development in Plasmodium parasites: knowing when it's time to commit. Nat Rev Microbiol 13:573-587

90. Kalyan S, Kabelitz D (2013) Defining the nature of human gammadelta T cells: a biographical sketch of the highly empathetic. Cell Mol Immunol 10:21-29

91. Kapulu MC, Njuguna P, Hamaluba MM (2018) Controlled human malaria infection in semi-immune Kenyan adults (CHMI-SIKA): a study protocol to investigate in vivo Plasmodium falciparum malaria parasite growth in the context of pre-existing immunity. Wellcome Open Res 3:155

92. Keller AN, Eckle SB, Xu W, Liu L, Hughes VA, Mak JY, Meehan BS, Pediongco T, Birkinshaw RW, Chen Z, Wang H, D'Souza C, Kjer-Nielsen L, Gherardin NA, Godfrey DI, Kostenko L, Corbett AJ, Purcell AW, Fairlie DP, McCluskey J, Rossjohn J (2017) Drugs and drug-like molecules can modulate the function of mucosal-associated invariant T cells. Nat Immunol 18:402-411

93. Kjer-Nielsen L, Patel O, Corbett AJ, le Nours J, Meehan B, Liu L, Bhati M, Chen Z, Kostenko L, Reantragoon R, Williamson NA, Purcell AW, Dudek NL, McConville M, O'Hair RA, Khairallah GN, Godfrey DI, Fairlie DP, Rossjohn J, McCluskey J (2012) MR1 presents microbial vitamin B metabolites to MAIT cells. Nature 491:717-723

94. Kojima S, Nagamine Y, Hayano M, Looareesuwan S, Nakanishi $\mathrm{K}$ (2004) A potential role of interleukin 18 in severe falciparum malaria. Acta Trop 89:279-284

95. Kumar R, Loughland JR, Ng SS et al (2020) The regulation of CD4(+) T cells during malaria. Immunol Rev 293:70-87

96. Kurup SP, Butler NS, Harty JT (2019) T cell-mediated immunity to malaria. Nat Rev Immunol 19:457-471

97. Langenberg MCC, Wammes LJ, Mccall MBB et al (2018) Controlled human malaria infection with graded numbers of Plasmodium falciparum NF135.C10- or NF166.C8-infected mosquitoes. Am J Trop Med Hyg 99:709-712

98. Le Bourhis L, Martin E, Peguillet I et al (2010) Antimicrobial activity of mucosal-associated invariant $\mathrm{T}$ cells. Nat Immunol 11:701-708 
99. Le Nours J, Gherardin NA, Ramarathinam SH et al (2019) A class of gammadelta $\mathrm{T}$ cell receptors recognize the underside of the antigen-presenting molecule MR1. Science 366:1522-1527

100. Legoux F, Bellet D, Daviaud C, el Morr Y, Darbois A, Niort K, Procopio E, Salou M, Gilet J, Ryffel B, Balvay A, Foussier A, Sarkis M, el Marjou A, Schmidt F, Rabot S, Lantz O (2019) Microbial metabolites control the thymic development of mucosal-associated invariant T cells. Science 366:494-499

101. Lell B, Mordmuller B, Dejon Agobe JC et al (2018) Impact of sickle cell trait and naturally acquired immunity on uncomplicated malaria after controlled human malaria infection in adults in Gabon. Am J Trop Med Hyg 98:508-515

102. Lepore M, Kalinichenko A, Colone A et al (2014) Parallel T-cell cloning and deep sequencing of human MAIT cells reveal stable oligoclonal TCRbeta repertoire. Nat Commun 5:3866

103. Lepore M, Kalinichenko A, Calogero S et al (2017) Correction: functionally diverse human $\mathrm{T}$ cells recognize non-microbial antigens presented by MR1. Elife 6

104. Lindberg BG, Merritt EA, Rayl M et al (2013) Immunogenic and antioxidant effects of a pathogen-associated prenyl pyrophosphate in Anopheles gambiae. PLoS One 8:e73868

105. Loh L, Wang Z, Sant S, Koutsakos M, Jegaskanda S, Corbett AJ, Liu L, Fairlie DP, Crowe J, Rossjohn J, Xu J, Doherty PC, McCluskey J, Kedzierska K (2016) Human mucosal-associated invariant $\mathrm{T}$ cells contribute to antiviral influenza immunity via IL-18-dependent activation. Proc Natl Acad Sci U S A 113: 10133-10138

106. Lyke KE, Burges R, Cissoko Y, Sangare L, Dao M, Diarra I, Kone A, Harley R, Plowe CV, Doumbo OK, Sztein MB (2004) Serum levels of the proinflammatory cytokines interleukin-1 beta (IL1beta), IL-6, IL-8, IL-10, tumor necrosis factor alpha, and IL12(p70) in Malian children with severe Plasmodium falciparum malaria and matched uncomplicated malaria or healthy controls. Infect Immun 72:5630-5637

107. Mak JY, Xu W, Reid RC et al (2017) Stabilizing short-lived Schiff base derivatives of 5-aminouracils that activate mucosalassociated invariant T cells. Nat Commun 8:14599

108. Matuschewski K (2017) Vaccines against malaria-still a long way to go. FEBS J 284:2560-2568

109. Mazier D, Beaudoin RL, Mellouk S, Druilhe P, Texier B, Trosper J, Miltgen F, Landau I, Paul C, Brandicourt O (1985) Complete development of hepatic stages of Plasmodium falciparum in vitro. Science 227:440-442

110. Mazier D, Renia L, Snounou G (2009) A pre-emptive strike against malaria's stealthy hepatic forms. Nat Rev Drug Discov 8:854-864

111. Menard R, Tavares J, Cockburn I et al (2013) Looking under the skin: the first steps in malarial infection and immunity. Nat Rev Microbiol 11:701-712

112. Mohan Rao LV, Esmon CT, Pendurthi UR (2014) Endothelial cell protein $\mathrm{C}$ receptor: a multiliganded and multifunctional receptor. Blood 124:1553-1562

113. Mordmuller B, Supan C, Sim KL et al (2015) Direct venous inoculation of Plasmodium falciparum sporozoites for controlled human malaria infection: a dose-finding trial in two centres. Malar J $14: 117$

114. Mori L, Lepore M, De Libero G (2016) The immunology of CD1and MR1-restricted T cells. Annu Rev Immunol 34:479-510

115. Morita CT, Jin C, Sarikonda G, Wang H (2007) Nonpeptide antigens, presentation mechanisms, and immunological memory of human Vgamma2Vdelta2 T cells: discriminating friend from foe through the recognition of prenyl pyrophosphate antigens. Immunol Rev 215:59-76

116. Mpina M, Maurice NJ, Yajima M et al (2017) Controlled human malaria infection leads to long-lasting changes in innate and innate-like lymphocyte populations. J Immunol 199:107-118
117. Mu J, Duan J, Makova KD, Joy DA, Huynh CQ, Branch OH, Li WH, Su XZ (2002) Chromosome-wide SNPs reveal an ancient origin for Plasmodium falciparum. Nature 418:323-326

118. Obiero JM, Shekalaghe S, Hermsen CC, Mpina M, Bijker EM, Roestenberg M, Teelen K, Billingsley PF, Sim BK, James ER, Daubenberger CA, Hoffman SL, Abdulla S, Sauerwein RW, Scholzen A (2015) Impact of malaria preexposure on antiparasite cellular and humoral immune responses after controlled human malaria infection. Infect Immun 83:2185-2196

119. Patel O, Kjer-Nielsen L, Le Nours J et al (2013) Recognition of vitamin $\mathrm{B}$ metabolites by mucosal-associated invariant T cells. Nat Commun 4:2142

120. Paul AS, Egan ES, Duraisingh MT (2015) Host-parasite interactions that guide red blood cell invasion by malaria parasites. Curr Opin Hematol 22:220-226

121. Phillips MA, Burrows JN, Manyando C et al (2017) Malaria. Nat Rev Dis Primers 3:17050

122. Pombo DJ, Lawrence G, Hirunpetcharat C, Rzepczyk C, Bryden M, Cloonan N, Anderson K, Mahakunkijcharoen Y, Martin LB, Wilson D, Elliott S, Elliott S, Eisen DP, Weinberg JB, Saul A, Good MF (2002) Immunity to malaria after administration of ultra-low doses of red cells infected with Plasmodium falciparum. Lancet 360:610-617

123. Pongponratn E, Riganti M, Punpoowong B, Aikawa M (1991) Microvascular sequestration of parasitized erythrocytes in human falciparum malaria: a pathological study. Am J Trop Med Hyg 44: 168-175

124. Ravens S, Schultze-Florey C, Raha S, Sandrock I, Drenker M, Oberdörfer L, Reinhardt A, Ravens I, Beck M, Geffers R, von Kaisenberg C, Heuser M, Thol F, Ganser A, Förster R, Koenecke C, Prinz I (2017) Human gammadelta T cells are quickly reconstituted after stem-cell transplantation and show adaptive clonal expansion in response to viral infection. Nat Immunol 18: 393-401

125. Reantragoon R, Corbett AJ, Sakala IG, Gherardin NA, Furness JB, Chen Z, Eckle SB, Uldrich AP, Birkinshaw RW, Patel O, Kostenko L, Meehan B, Kedzierska K, Liu L, Fairlie DP, Hansen TH, Godfrey DI, Rossjohn J, McCluskey J, Kjer-Nielsen L (2013) Antigen-loaded MR1 tetramers define T cell receptor heterogeneity in mucosal-associated invariant T cells. J Exp Med 210:2305-2320

126. Ribot JC, Debarros A, Silva-Santos B (2011) Searching for "signal 2": costimulation requirements of gammadelta T cells. Cell Mol Life Sci 68:2345-2355

127. Ribot JC, Neres R, Zuzarte-Luis V et al (2019) Gammadelta-T cells promote IFN-gamma-dependent Plasmodium pathogenesis upon liver-stage infection. Proc Natl Acad Sci U S A 116:99799988

128. Rigau M, Ostrouska S, Fulford TS et al (2020) Butyrophilin 2A1 is essential for phosphoantigen reactivity by gammadelta $\mathrm{T}$ cells. Science

129. Rock EP, Sibbald PR, Davis MM, Chien YH (1994) CDR3 length in antigen-specific immune receptors. J Exp Med 179:323-328

130. Roestenberg M, Bijker EM, Sim BKL, Billingsley PF, James ER, Bastiaens GJH, Teirlinck AC, Scholzen A, Teelen K, Arens T, van der Ven A, Gunasekera A, Chakravarty S, Velmurugan S, Hermsen CC, Sauerwein RW, Hoffman SL (2013) Controlled human malaria infections by intradermal injection of cryopreserved Plasmodium falciparum sporozoites. Am J Trop Med Hyg 88:513

131. Roestenberg M, Hoogerwerf MA, Ferreira DM, Mordmüller B, Yazdanbakhsh M (2018) Experimental infection of human volunteers. Lancet Infect Dis 18:e312-e322

132. Roussilhon C, Agrapart M, Ballet JJ, Bensussan A (1990) T lymphocytes bearing the gamma delta $\mathrm{T}$ cell receptor in patients with acute Plasmodium falciparum malaria. J Infect Dis 162:283-285 
133. Roussilhon C, Agrapart M, Guglielmi P et al (1994) Human TcR gamma delta+ lymphocyte response on primary exposure to Plasmodium falciparum. Clin Exp Immunol 95:91-97

134. Rowell DL, Eckmann L, Dwinell MB et al (1997) Human hepatocytes express an array of proinflammatory cytokines after agonist stimulation or bacterial invasion. Am J Phys 273:G322-G332

135. Roy S, Ly D, Castro CD et al (2016) Molecular analysis of lipidreactive Vdelta1 gammadelta $T$ cells identified by $\mathrm{CD} 1 \mathrm{c}$ tetramers. J Immunol 196:1933-1942

136. Rutishauser T (2019) Cellular immunity in Tanzanian volunteers upon malaria vaccination and controlled human malaria infection. In Dissertation, University of Basel, Switzerland

137. Rutishauser T, Lepore M, Di Blasi D et al (2019) Activation of TCR Vdelta1(+) and Vdelta1(-)Vdelta2(-) gammadelta T cells upon controlled infection with Plasmodium falciparum in Tanzanian volunteers. J Immunol

138. Salmon BL, Oksman A, Goldberg DE (2001) Malaria parasite exit from the host erythrocyte: a two-step process requiring extraerythrocytic proteolysis. Proc Natl Acad Sci U S A 98:271276

139. Sandstrom A, Peigne CM, Leger A et al (2014) The intracellular B30.2 domain of butyrophilin 3A1 binds phosphoantigens to mediate activation of human Vgamma9Vdelta2 T cells. Immunity 40: 490-500

140. Sauerwein RW, Roestenberg M, Moorthy VS (2011) Experimental human challenge infections can accelerate clinical malaria vaccine development. Nat Rev Immunol 11:57-64

141. Schmaler M, Colone A, Spagnuolo J, Zimmermann M, Lepore M, Kalinichenko A, Bhatia S, Cottier F, Rutishauser T, Pavelka N, Egli A, Azzali E, Pieroni M, Costantino G, Hruz P, Sauer U, Mori L, de Libero G (2018) Modulation of bacterial metabolism by the microenvironment controls MAIT cell stimulation. Mucosal Immunol 11:1060-1070

142. Seilie AM, Chang M, Hanron AE, Billman ZP, Stone BC, Zhou K, Olsen TM, Daza G, Ortega J, Cruz KR, Smith N, Healy SA, Neal J, Wallis CK, Shelton L, Mankowski TV, Wong-Madden S, Mikolajczak SA, Vaughan AM, Kappe SHI, Fishbaugher M, Betz W, Kennedy M, Hume JCC, Talley AK, Hoffman SL, Chakravarty S, Sim BKL, Richie TL, Wald A, Plowe CV, Lyke KE, Adams M, Fahle GA, Cowan EP, Duffy PE, Kublin JG, Murphy SC (2019) Beyond blood smears: qualification of Plasmodium 18S rRNA as a biomarker for controlled human malaria infections. Am J Trop Med Hyg 100:1466-1476

143. Seydel KB, Milner DA Jr, Kamiza SB et al (2006) The distribution and intensity of parasite sequestration in comatose Malawian children. J Infect Dis 194:208-205

144. Sheehy SH, Spencer AJ, Douglas AD et al (2013) Optimising controlled human malaria infection studies using cryopreserved P. falciparum parasites administered by needle and syringe. PLoS One 8:e65960

145. Shekalaghe S, Rutaihwa M, Billingsley PF, Chemba M, Daubenberger CA, James ER, Mpina M, Ali Juma O, Schindler T, Huber E, Gunasekera A, Manoj A, Simon B, Saverino E, Church LWP, Hermsen CC, Sauerwein RW, Plowe C, Venkatesan M, Sasi P, Lweno O, Mutani P, Hamad A, Mohammed A, Urassa A, Mzee T, Padilla D, Ruben A, Sim BKL, Tanner M, Abdulla S, Hoffman SL (2014) Controlled human malaria infection of Tanzanians by intradermal injection of aseptic, purified, cryopreserved Plasmodium falciparum sporozoites. Am J Trop Med Hyg 91:471-480

146. Sherwood AM, Desmarais C, Livingston RJ et al (2011) Deep sequencing of the human TCRgamma and TCRbeta repertoires suggests that TCRbeta rearranges after alphabeta and gammadelta T cell commitment. Sci Transl Med 3:90ra61

147. Shi Y, Liu CH, Roberts AI, Das J, Xu G, Ren G, Zhang Y, Zhang L, Yuan ZR, Tan HS, Das G, Devadas S (2006) Granulocyte- macrophage colony-stimulating factor (GM-CSF) and T-cell responses: what we do and don't know. Cell Res 16:126-133

148. Spada FM, Grant EP, Peters PJ, Sugita M, Melián A, Leslie DS, Lee HK, van Donselaar E, Hanson DA, Krensky AM, Majdic O, Porcelli SA, Morita CT, Brenner MB (2000) Self-recognition of CD1 by gamma/delta T cells: implications for innate immunity. $\mathrm{J}$ Exp Med 191:937-948

149. Stanisic DI, Cutts J, Eriksson E, Fowkes FJ, Rosanas-Urgell A, Siba P, Laman M, Davis TM, Manning L, Mueller I, Schofield L (2014) Gammadelta T cells and CD14+ monocytes are predominant cellular sources of cytokines and chemokines associated with severe malaria. J Infect Dis 210:295-305

150. Sturm A, Amino R, Van De Sand C et al (2006) Manipulation of host hepatocytes by the malaria parasite for delivery into liver sinusoids. Science 313:1287-1290

151. Suliman S, Murphy M, Musvosvi M et al (2019) MR1independent activation of human mucosal-associated invariant $\mathrm{T}$ cells by mycobacteria. J Immunol 203:2917-2927

152. Tagaya Y, Bamford RN, Defilippis AP et al (1996) IL-15: a pleiotropic cytokine with diverse receptor/signaling pathways whose expression is controlled at multiple levels. Immunity 4:329-336

153. Tan J, Piccoli L, Lanzavecchia A (2019) The antibody response to Plasmodium falciparum: cues for vaccine design and the discovery of receptor-based antibodies. Annu Rev Immunol 37:225-246

154. Tang XZ, Jo J, Tan AT et al (2013) IL-7 licenses activation of human liver intrasinusoidal mucosal-associated invariant $\mathrm{T}$ cells. J Immunol 190:3142-3152

155. Taniguchi T, Md Mannoor K, Nonaka D et al (2017) A unique subset of gammadelta $\mathrm{T}$ cells expands and produces IL-10 in patients with naturally acquired immunity against falciparum malaria. Front Microbiol 8:1288

156. Teirlinck AC, Roestenberg M, Bijker EM, Hoffman SL, Sauerwein RW, Scholzen A (2015) Plasmodium falciparum infection of human volunteers activates monocytes and CD16+ dendritic cells and induces upregulation of CD16 and CD1c expression. Infect Immun 83:3732-3739

157. Tilloy F, Treiner E, Park SH et al (1999) An invariant T cell receptor alpha chain defines a novel TAP-independent major histocompatibility complex class Ib-restricted alpha/beta $\mathrm{T}$ cell subpopulation in mammals. J Exp Med 189:1907-1921

158. Toubal A, Nel I, Lotersztajn S, Lehuen A (2019) Mucosalassociated invariant $\mathrm{T}$ cells and disease. Nat Rev Immunol 19: 643-657

159. Treiner E, Duban L, Bahram S, Radosavljevic M, Wanner V, Tilloy F, Affaticati P, Gilfillan S, Lantz O (2003) Selection of evolutionarily conserved mucosal-associated invariant $\mathrm{T}$ cells by MR1. Nature 422:164-169

160. Turner L, Lavstsen T, Berger SS et al (2013) Severe malaria is associated with parasite binding to endothelial protein $\mathrm{C}$ receptor. Nature 498:502-505

161. Uldrich AP, Le Nours J, Pellicci DG et al (2013) CD1d-lipid antigen recognition by the gammadelta TCR. Nat Immunol 14: $1137-1145$

162. Urban BC, Mwangi T, Ross A, Kinyanjui S, Mosobo M, Kai O, Lowe B, Marsh K, Roberts DJ (2001) Peripheral blood dendritic cells in children with acute Plasmodium falciparum malaria. Blood 98:2859-2861

163. Urban BC, Hien TT, Day NP, Phu NH, Roberts R, Pongponratn E, Jones M, Mai NT, Bethell D, Turner GD, Ferguson D, White NJ, Roberts DJ (2005) Fatal Plasmodium falciparum malaria causes specific patterns of splenic architectural disorganization. Infect Immun 73:1986-1994

164. Ussher JE, Bilton M, Attwod E, Shadwell J, Richardson R, de Lara C, Mettke E, Kurioka A, Hansen TH, Klenerman P, Willberg CB (2014) CD161++ CD8+ T cells, including the 
MAIT cell subset, are specifically activated by IL-12+IL-18 in a TCR-independent manner. Eur J Immunol 44:195-203

165. Van Rhijn I, Moody DB (2015) CD1 and mycobacterial lipids activate human T cells. Immunol Rev 264:138-153

166. Van Wilgenburg B, Scherwitzl I, Hutchinson EC et al (2016) MAIT cells are activated during human viral infections. Nat Commun 7:11653

167. Vavassori S, Kumar A, Wan GS, Ramanjaneyulu GS, Cavallari M, el Daker S, Beddoe T, Theodossis A, Williams NK, Gostick E, Price DA, Soudamini DU, Voon KK, Olivo M, Rossjohn J, Mori L, de Libero G (2013) Butyrophilin 3A1 binds phosphorylated antigens and stimulates human gammadelta $\mathrm{T}$ cells. Nat Immunol 14:908-916

168. Vroom TM, Scholte G, Ossendorp F, Borst J (1991) Tissue distribution of human gamma delta $\mathrm{T}$ cells: no evidence for general epithelial tropism. J Clin Pathol 44:1012-1017

169. Watanabe H, Weerasinghe A, Miyaji C, Sekikawa H, Toyabe S, Mannor MK, Morshed SR, Halder RC, Kobayashi J, Toma H, Sato Y, Iwai K, Matsuoka H, Abo T (2003) Expansion of unconventional $\mathrm{T}$ cells with natural killer markers in malaria patients. Parasitol Int 52:61-70

170. Waterfall M, Black A, Riley E (1998) Gammadelta+ T cells preferentially respond to live rather than killed malaria parasites. Infect Immun 66:2393-2398

171. White NJ (2017) Malaria parasite clearance. Malar J 16:88

172. Who (2018) Malaria report 2018. In

173. Willcox BE, Willcox CR (2019) Gammadelta TCR ligands: the quest to solve a 500-million-year-old mystery. Nat Immunol 20: $121-128$
174. Willcox CR, Pitard V, Netzer S, Couzi L, Salim M, Silberzahn T, Moreau JF, Hayday AC, Willcox BE, Déchanet-Merville J (2012) Cytomegalovirus and tumor stress surveillance by binding of a human gammadelta $\mathrm{T}$ cell antigen receptor to endothelial protein C receptor. Nat Immunol 13:872-879

175. Willcox CR, Vantourout P, Salim M et al (2019) Butyrophilin-like 3 directly binds a human Vgamma4(+) T cell receptor using a modality distinct from clonally-restricted antigen. Immunity 51(813-825):e814

176. Worku S, Bjorkman A, Troye-Blomberg M et al (1997) Lymphocyte activation and subset redistribution in the peripheral blood in acute malaria illness: distinct gammadelta+ T cell patterns in Plasmodium falciparum and P. vivax infections. Clin Exp Immunol 108:34-41

177. Wykes MN, Good MF (2009) What have we learnt from mouse models for the study of malaria? Eur J Immunol 39:2004-2007

178. Yam XY, Niang M, Madnani KG, Preiser PR (2017) Three is a crowd - new insights into rosetting in Plasmodium falciparum. Trends Parasitol 33:309-320

179. Zeng X, Wei YL, Huang J, Newell EW, Yu H, Kidd BA, Kuhns MS, Waters RW, Davis MM, Weaver CT, Chien YH (2012) Gammadelta $T$ cells recognize a microbial encoded $\mathrm{B}$ cell antigen to initiate a rapid antigen-specific interleukin-17 response. Immunity 37:524-534

Publisher's note Springer Nature remains neutral with regard to jurisdictional claims in published maps and institutional affiliations. 